Discussion Paper No. 13-067

\title{
Offshoring and Relative Labor Demand from a Task Perspective
}

Jan Hogrefe

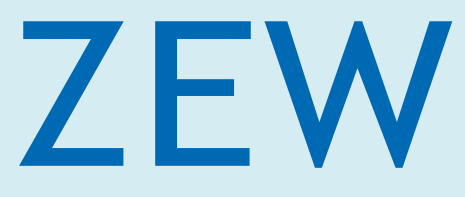

Zentrum für Europäische Wirtschaftsforschung $\mathrm{GmbH}$ Centre for European Economic Research 
Discussion Paper No. 13-067

\title{
Offshoring and Relative Labor Demand from a Task Perspective
}

\author{
Jan Hogrefe
}

Download this ZEW Discussion Paper from our ftp server:

http://ftp.zew.de/pub/zew-docs/dp/dp13067.pdf

Die Discussion Papers dienen einer möglichst schnellen Verbreitung von neueren Forschungsarbeiten des ZEW. Die Beiträge liegen in alleiniger Verantwortung der Autoren und stellen nicht notwendigerweise die Meinung des ZEW dar.

Discussion Papers are intended to make results of ZEW research promptly available to other economists in order to encourage discussion and suggestions for revisions. The authors are solely responsible for the contents which do not necessarily represent the opinion of the ZEW. 


\section{Non-technical summary}

Since trade is becoming more of a task-related phenomenon due to the increase in offshoring activities by firms, the pattern of effects across workers is changing as well. In particular, the skill-based characterization of differentially affected groups falls short of comprehensively capturing the effects. Offshoring occurs based on relocation cost for single occupations, which do not necessarily reflect skill intensities. This paper puts this claim to a test by analyzing industry level relative labor demand from a task perspective.

First, a model is developed to describe the mechanisms underlying the link between offshoring and shifts in employment and cost shares of tasks. This model explicitly treats occupations as fixed bundles of tasks which are, as a whole, subject to the offshoring decision. This is a crucial difference to skill-based approaches, in which individuals either supply high-skilled or low-skilled labor, with complete mobility across industries or stages of production. Furthermore, the model highlights the between-occupation dimension in task share changes in the economy. The model introduces a sorting mechanism of individuals across occupations, which relies on a trade off between occupations specific wages and individual abilities in terms of effort needed for the execution of certain tasks. In such a setting, an overall fall in offshoring costs can shift the cut-off occupation, which separates home from foreign production, such that the range of occupations at home shrinks. Crucially, this remaining range of occupations is characterized by a higher non-routine and interactive task content. Since workers whose jobs have gone offshore optimally re-sort into these occupations, average employment shares and cost shares of routine and non-interactive tasks fall in the home economy. Introducing occupations as bundles of tasks provides a new and consistent way of theoretically sound estimation of relative labor demand for tasks.

Second, the theoretical predictions are tested with industry level data from German manufacturing. A clear and robust result emerges. An increase in offshoring significantly reduces home country relative demand for routine and non-interactive tasks - in particular if this offshoring is directed towards non-OECD countries. This result is robust to various alterations and the use of instrumental variable methods. The additional value compared to skill related measures is demonstrated by the fact that this demand shift is also observed when controlling for the skill composition of industries. The main results show offshoring to account for up to $24 \%$ of the observed "task-upgrading" over the period 1998-2007. 


\section{Das Wichtigste in Kürze}

Im Rahmen der fortschreitenden Globalisierung wird der Außenhandel immer stärker durch OffshoringAktivitäten charakterisiert. Damit gehen wichtige neue Effekte auf dem Arbeitsmarkt einher. Insbesondere wird in einer aufstrebenden Literatur untersucht, ob es der genaue Tätigkeitsinhalt eines Berufes ist, welcher die Verlagerungskosten und damit die Auslagerungsentscheidung bestimmt. Diese durch Arbeitsinhalte bestimmten Kosten sind nicht notwendigerweise über die klassische Unterscheidung zwischen hoch- und niedrigqualifizierten Arbeitnehmern in den jeweiligen Berufen abbildbar. In diesem Papier wird die obige Hypothese einer durch Offshoring sinkenden relativen Nachfrage nach routinebasierten und nicht-interaktiven Tätigkeiten getestet und somit das Problem der relativen Arbeitsnachfrage aus einer "Task-Perspektive" beleuchtet.

Zunächst wird ein theoretisches Modell entwickelt, welches die Grundlage für spätere Schätzungen liefert. Dieses Modell betrachte Berufe explizit als Bündel von Tätigkeiten, welche als Ganzes der Auslagerungsentscheidung zu Grunde liegen. Dieser Ansatz stellt einen Bruch mit vergangener Modellierung dar, welche nahezu ausschließlich auf bildungsbasierte und in der Reallokation völig freie Faktoren setzte. Das Modell führt einen Mechanismus der optimalen Berufswahl ein, welcher auf einer individuellen Optimierungsentscheidung hinsichtlich der für eine Arbeit notwendigen Anstrengung basiert. Im Modell führt ein Rückgang der allgemeinen Kosten für Offshoring dazu, dass manche Berufe verlagert werden und sich die entsprechenden Arbeitnehmer neu "einsortieren". Da komplexere Tätigkeiten weniger leicht auslagerbar sind, werden durch verstärktes Offshoring in einem neuen Gleichgewicht relativ mehr Menschen in Berufen mit einem höheren Anteil an komplexeren Tätigkeiten beschäftigt sein als vorher.

Anschließend werden die theoretischen Hypothesen einer ökonometrischen Untersuchung unterzogen. Für ein Panel verschiedener Sektoren des Verarbeitenden Gewerbes in Deutschland zeigt sich zwischen 1998 und 2007 ein klares und robustes Resultat: Offshoring führt zu einem Rückgang der Nachfrage nach routinebasierten und nicht-interaktien Tätigkeiten auf Sektorebene. Ein besonders starker Effekt zeigt sich, wenn Offshoring in nicht-OECD Länder betrachtet wird. Dieser Rückgang ist stark durch eine Reallokation von Berufen getrieben. Insgesamt kann der beobachtete Anstieg des Offshoring bis zu 24\% der gemessenen aggregierten Tätigkeitsverschiebung abbilden. Eine weitere wichtige Erkenntnis ist, dass auch bei Berücksichtigung von Qualifikationsniveaus innerhalb der Sektoren eine Reduktion der relativen Arbeitsnachfrage nach einfachen Tätigkeiten zu beobachten ist. Zudem erweisen sich die Resultate robust gegenüber eines Instrumenten-Schätzansatzes. Es scheint als sei die "Task-Perspektive" eine neue und wichtige Dimension in der Heterogenität der Effekte von Globalisierung in modernen Arbeitsmärkten. 


\title{
Offshoring and Relative Labor Demand from a Task Perspective*
}

\author{
Jan Hogrefe \\ ZEW Mannheim
}

September 2013

\begin{abstract}
This paper provides new evidence on how offshoring shifts relative labor demand for tasks at the industry level. A novel theoretical mechanism, based on sorting of heterogeneous workers into occupations with task dependent offshoring cost, guides estimation. Cost shares of tasks are linked to offshoring in a panel estimation using German data for 1998-2007. It is shown that offshoring shifts home country relative labor demand towards more complex tasks with higher relocation cost. This demand shift holds when controlling for an industry's skill composition and is particularly strong for offshoring to non-OECD countries.
\end{abstract}

keywords: trade, offshoring, tasks, relative labor demand JEL codes: F16, F66, J23

${ }^{*}$ This version: September 2013. For very helpful remarks and suggestions, I would like to thank Claudia Buch, Gordon Hanson, Sanne Hiller, Benjamin Jung, Marcus Kappler, Wilhelm Kohler, Suzanne Kok, Marc Muendler, James Rauch, Anna Salomons, Ebru Voyvoda, and Jens Wrona as well as conference, workshop, and seminar participants at University of California San Diego, Goettingen University, University of Tuebingen, ZEW Mannheim, the BIBB TASK II 2012 workshop in Bonn, RES 2012 annual conference in Cambridge (UK), and the WIEM 2013 in Warsaw. All remaining errors are, of course, my own. I would also like to thank the economics department of the University of California, San Diego for its hospitality while much of the current paper was written. This paper is an abbreviated and slightly revised version of chapter 4 of my doctoral thesis "Income and Employment Effects of Trade and Offshoring in Modern Labor Markets", which I completed at the University of Tuebingen.

Further projects of the author can be found at www.zew.de/staff_jhf. More information on the ZEW is available at ww. zew.eu.

Author contact details: Jan Hogrefe, Centre for European Economic Research (ZEW), Mannheim. Address: L7,1 68161 Mannheim, Germany. Email: hogrefe[at]zew.de. Phone: +49 (0)621 1235348 


\section{Introduction}

According to a growing strand of literature, a large part of modern trade - often referred to as offshoring - is best conceptualized as trade based on job-tasks, meaning that it is driven by international allocation of production at the level of narrowly defined tasks. Grossman \& Rossi-Hansberg (2008) have theoretically described the implications of this trade in tasks for wages and pointed out that the effects of offshoring are no longer unanimously described along the lines of worker's formal education levels - a point also emphasized by Baldwin (2006). The implications of this approach for workers are crucial: Since the nature of trade is changing, the lines defining heterogeneity in the effect of globalization on individuals might have to be redrawn as well. Distinctions based on formal education levels are looking increasingly unfitting. Empirically, concepts based on how routine and rules-based a certain job is have gained importance (Autor et al. 2003, Levy \& Murnane 2004, Acemoglu \& Autor 2011). Additionally, proximity needs and interactivity characteristics are strongly correlated with how easily occupations can be shifted abroad (Blinder 2006). Importantly, both of these concepts are independent of industries and are not necessarily correlated with formal skill levels. Hence, they emerge as a novel dimension in the analysis of wages and employment effects in modern open economies.

Following these recent developments, empirical approaches to estimating the link between offshoring and relative labor demand need to be able to incorporate the task perspective. Early work on offshoring in Feenstra \& Hanson (1996), Kohler (2004), or Hijzen et al. (2005) treated individuals as either high-skilled or low-skilled and goods as embodying different amounts of these two types of labor. In such a framework, the production process can be split up and some stages may be offshored. Empirical analysis of the resulting effects often builds on estimation of zero profit conditions of labor demand functions arising from translog production functions. Yet, there is no role for tasks. Recent work seeks to fill this gap and to combine this approach with the task trade paradigm. As an example, Becker et al. (2013) draw motivation from Grossman \& Rossi-Hansberg (2008), and the task trade idea of freely mobile tasks as an additional layer within high-skill and low-skill labor inputs. Yet, the analysis in Grossman \& Rossi-Hansberg (2008) is missing the concept of occupations, which, in turn, is at the heart of modern empirical measurement of task contents (Ebenstein et al. 2013, Crinò 2010, Baumgarten et al. 2013). Becker et al. (2013) ultimately put a focus on estimation and show important insights from estimating firm level relative labor demand for tasks in a way that resembles previous skill-based approaches derived 
from a translog framework - with task content based on occupation level task intensities. However, an occupation is conceptually different from the intermediate production stages in the Feenstra \& Hanson (1996) model, were combinations of high-skill and low-skill labor inputs are separately contracted in the market. In particular, in this latter model, individuals supply either of the two factors to the market and are freely mobile across production stages. This is at odds with the concept of occupations - namely that they are bundles of different tasks, contracted on the labor market as a package-deal.

This paper develops a new theoretical underpinning for estimating the effect of trade on relative labor demand, which places the aforementioned lines of distinction between different tasks at the center of the analysis. The main idea is to bring together theory and empirics by modelling labor contracts as being based on occupations which represent bundles of different tasks. On the labor market, heterogeneous individuals are sorting themselves into different occupations in line with their abilities to perform different types of tasks. According to this theory, the effect of offshoring on relative labor demand and wages works through changing the sorting environment for individuals and ultimately leads to a new sorting equilibrium and new task content of domestic labor demand. This paper lays out the theory and subsequently uses it to provide novel empirical estimates confirming that offshoring negatively affects relative labor demand for routine and noninteractive tasks at the industry level.

Section 2 describes the sorting model of the labor market in more detail. In the proposed framework, individuals are endowed with different abilities, which determine the effort needed for the execution of a particular task. Based on these abilities, and occupation specific wages, they sort into occupations, which are in turn characterized by fixed requirements of tasks. With individuals optimally sorted into jobs, firms face the decision whether to offshore any given occupation. The costs of offshoring are conceptualized following the general idea of Kohler (2004) and Grossman \& Rossi-Hansberg (2008), adapted to a framework with bundling of tasks in occupations. They include a general component, which is equal for all occupations, and an idiosyncratic one directly related to the occupation level task intensity. The more intensively an occupation uses non-routine and interactive tasks, the more costly it will be to offshore. This assumption is linked to the fixed and indivisible bundling of tasks in occupations. Such bundling is common in European labor markets and mostly due to binding work contracts which specify job contents. Furthermore, it is 
commonly assumed in recent contributions in the labor market literature such as Autor \& Handel (2013) or Firpo et al. (2011). ${ }^{1}$

Offshoring is triggered by a downward shift in the general cost component of offshoring costs, possibly due to trade liberalization or technological innovations. Given such a cost reduction, the offshore production of some occupations might become profitable, depending on the characteristics of the tasks bundled into them. Individuals previously employed in these jobs will re-sort into the now optimal occupation, given the reduced range over which optimization takes place. As a result, and given firm level optimal decisions, the new equilibrium will have individuals being employed in occupations which are on average more intensive in non-routine and interactive tasks. Importantly, individuals with the same underlying abilities, through resorting into different occupations, now derive a larger share of income from these tasks in the new equilibrium. Hence, the cost share of routine and non-interactive tasks in domestic labor demand will fall with offshoring. This paper thus contributes a theoretical approach, linking offshoring and relative labor demand for tasks which is consistent with using data that treats occupations as bundles of tasks.

The following sections take the theoretical approach to the data. The prediction regarding relative labor demand for tasks is tested in a panel set-up at the industry level for the years 1998 - 2007, using data from the German manufacturing sector. The data set used for estimation combines information on offshoring, derived from yearly input-output tables and industry level trade data, with industry level employment shares and cost shares of different tasks, which in turn are calculated from information on individual level earnings and employment. Task data are compiled from survey responses as a direct account of reported work content, rather than being based on external assessments. This paper's results uncover a more nuanced effect on relative labor demand than a skill-based analysis does since workers with the same educational achievement usually carry out a multitude of job specific tasks. Consequently, the question of whether the task perspective indeed sheds light on a new aspect is answered by also estimating relative demand for tasks conditional on the skill-composition of an industry. The results indeed point to important effects operating within industries and within skill groups. Offshoring is shown to significantly reduce

\footnotetext{
${ }^{1}$ Regarding occupational task composition as fixed is also consistent with estimating task employment and wage responses with time-invariant data on which tasks make up an occupation. This data structure is common to almost any data on tasks used in academic research. Examples for data sets on task content without a (short-run) time variation are the German BIBB data used here and in Becker et al. (2013), or the O*NET data base for the US (see Crinò 2010, Costinot et al. 2011), which are widely used in the literature - also on a number of topics beyond international economics. Using such data demands an approach which is consistent with this data structure, such as the one presented here.
} 
relative labor demand for routine and non-interactive tasks with and without explicitly controlling for the share of high-skilled or medium-skilled individuals in the labor force. The impact offshoring has on relative labor demand for tasks is particularly strong if production offshoring is directed towards non-OECD countries. This link is shown to be robust across various measures of task-based labor demand and multiple estimation methods, including instrumental variables models.

The paper adds to some important recent contributions to the task-based empirical work on the labor market effects of offshoring. Effects on individual wages are studied in Ebenstein et al. (2013) and Baumgarten et al. (2013), for instance. Crinò (2010) analyses relative labor demand at the occupational level. Among others, Autor et al. (2006), Acemoglu \& Autor (2011), and Goos et al. $(2009,2010)$ document that more offshorable (routine) jobs show relative employment losses, contributing to the polarization of the labor markets in the U.S and in Europe, respectively. At the level of the firm, Becker et al. (2013) produce evidence that German multinationals reduce relative labor demand for routine tasks at home when expanding employment in their affiliates abroad. On a more aggregate level, and taking a long-term perspective, Kemeny \& Rigby (2012) show that imports from developing countries are linked to the decline of routine task intensive employment in US manufacturing since the 1970s. While most of the emerging literature on the topic has a focus on the firm or individual level, the present paper tackles the issue at the industry level. It thus delivers an analysis also capturing more aggregate effects on labor demand arising from linkages between offshoring firms and others. Labor demand by offshoring firms may not be representative of sector or country level trends if individuals, set free by such firms, are re-employed and perform similar tasks in non-offshoring firms. In this case, the firm level effect measured by the previous literature would uncover differences in labor demand across heterogeneous firms, rather than aggregate trends in employment structures. A comprehensive study analyzing the connection between manufacturing offshoring and relative labor demand from a task perspective at such a more aggregate level thus far is missing.

\section{Theoretical considerations}

The classic theoretical background for much recent work on offshoring and relative labor demand is Feenstra \& Hanson (1996). This skill-based model is not easily transferable to an analysis of the link between offshoring and relative labor demand for tasks, however. Feenstra \& Hanson (1996) 
features a continuum of production stages, which each require the input of high-skilled and lowskilled labor, which is contracted on labor markets. These stages of production are subject to the offshoring decision and the skill shares determine how attractive such a move would be. In Feenstra \& Hanson (1996) there is no role for tasks. In contrast to this model, modern theory introduces the notion of tasks, which are differently tradable, depending on how routine or interactive they are. These characteristics do not have to coincide with education-based categories of skills, however. In the model by Grossman \& Rossi-Hansberg (2008), tasks are built-in as an additional layer within high-skilled and low-skilled labor. A single task is always connected to either high-skilled or low-skilled labor and labor types are both mobile across industries.

The model presented here differs in its conceptualization of tasks. On the labor market, different and fixed bundles of tasks are contracted. These bundles are called occupations and are made up of two fundamental types of tasks: $R$-tasks, which comprise routine and non-interactive activities, and $N$-tasks, collecting non-routine and interactive job contents. The offshoring cost of an occupation is determined by the proportion of $R$-tasks and $N$-tasks. ${ }^{2}$ In both the domestic and foreign market, different occupations pay different wages but individuals within each occupation earn the same wage. Individuals, in turn, are heterogeneous and endowed with varying amounts of talent for the performance of $R$-tasks and $N$-tasks, respectively. Based on these talents, which determine the amount of effort needed to produce one effective unit of labor in a given occupation, an individual self-selects into one specific occupation, depending on the unit wage offered for the respective bundle of tasks in different occupations. The crucial difference to both the Feenstra \& Hanson (1996) and the Grossman \& Rossi-Hansberg (2008)-type models is the bundling of tasks. The consequence is that tasks cannot be treated as separate factors being supplied to the market independently. ${ }^{3}$ In the following, the task-based characterization of the labor market will be developed, building on insights recently put forth in Liu \& Trefler (2011) and Autor \& Handel (2013), that in turn represent modern interpretations of Roy (1951)-type models. ${ }^{4}$ Subsequently, it will be described in more detail how an exogenous change in the costs of offshoring leads to changes in the relative demand for tasks - changes which are tightly linked to shifts in the occupational

\footnotetext{
${ }^{2}$ See section 3 for more details on the classification of tasks.

${ }^{3}$ This equally applies to many empirical approaches using the more general translog production function as a starting point for deriving a reduced form empirical relationship. Such an approach also necessarily requires the different tasks to be independently supplied to the market - which is neither consistent with fixed task bundling at the occupation level nor with how task contents are usually measured in terms of occupations' "task scores".

${ }^{4}$ While the set up of the labor market is similar in these papers, there are distinct differences in terms of how offshoring is conceptualized. In Autor \& Handel (2013) there is no direct link to offshoring or trade. In Liu \& Trefler (2011) offshoring occurs as a shift of tasks out of an occupation. In contrast, the mechanism here follows the idea of entire occupations being subject to the relocation decision of firms.
} 
employment structure towards more non-routine and interactive jobs.

There is one final good $Y$ being produced from a range of intermediate activities $k$, with $[k=1, \ldots, K]$. These intermediate activities are different occupations, which use labor $L=\{N, R\}$ and capital $B$ to produce output. ${ }^{5}$ Each occupation requires the performance of a different mix of tasks. That is, some occupations more intensively use non-routine and interactive $N$-tasks, while in others most of the tasks are routine or non-interactive $(R)$. The amount of these tasks required within each occupation is fixed. Hence the production structure of an occupation $k$ is described by $\phi_{k}=\left\{N_{k}, R_{k}, B_{k}\right\}$. The occupations are furthermore ordered such that a higher $\phi_{k}$ means a higher relative intensity of $N$-tasks.

Individuals are heterogeneous. Each individual $i$ is characterized by specific abilities in the performance of tasks, which are denoted by $A_{i N}$ and $A_{i R}$ for $N$-tasks and $R$-tasks, respectively. These abilities can be seen as individual talents - whether innate or acquired through education and training. Importantly, they are regarded as exogenously given and fixed. When supplied to the labor market, they will determine the amount of effort needed to deliver an efficiency unit of labor input of occupation $k$ in a way that a higher $A_{i N}$ is connected to less effort needed in occupations intensive in $N$-tasks. Framing the sorting mechanism in terms of effort is a crucial difference to recent contributions like Ohnsorge \& Trefler (2007) and Liu \& Trefler (2011), where individual abilities determine individual earnings in an occupation. In contrast, the mechanism introduced here will not generate different earnings across individuals within each occupation but instead will preserve a common occupation specific wage. Sorting works through the mechanism that differently endowed individuals will need different amounts of effort for attaining that wage, which generates disutility and thus leads to a trade-off between higher wages and higher disutility from effort. That is, the individuals select themselves into a certain occupation so as to maximize the wage received per unit of effort. A single occupation specific wage is an important feature as this wage is the basis firms will decide on when considering shifting certain occupations offshore. ${ }^{6}$ Using this effort-based individual sorting, a more formal characterization of occupations from an

\footnotetext{
${ }^{5}$ Capital in this case is assumed to be freely mobile across occupations as well as internationally and thus has one single equilibrium price $b$. Furthermore, it is assumed to be a fixed input in the short-run, which takes it out of the decision regarding a firm's optimal choice of production location.

${ }^{6}$ An occupation specific wage seems like a plausible assumption given union bargaining over wages and fixed pay scales in many European industries.
} 
individual's perspective is given by:

$$
F_{k i}\left(A_{i N}, A_{i R}\right)=A_{i N}^{\phi_{k}} A_{i R}^{1-\phi_{k}}
$$

where $1 / F_{k i}$ is the amount of individual effort needed to generate a unit of effective occupation $k$-type labor with individual abilities $A_{i N}$ and $A_{i R}$. Following Liu \& Trefler (2011), in order to derive the individual sorting rule, it is useful to define $r=\ln A_{i R}$ and $n=\ln A_{i N}$ and to write $f_{i k}(n, r)$ as the function implicitly defined by $F_{k i}\left(A_{i N}, A_{i R}\right)=f_{i k}(n, r)$. Taking logs, a transformed expression for the relation between individual abilities and the effort needed to perform a given occupation derives as:

$$
\ln f_{i k}(n, r)=\phi_{k} n+\left(1-\phi_{k}\right) r=\phi_{k}(n-r)+r
$$

which is the same expression as in Liu \& Trefler (2011), yet with a different interpretation that replaces extra earnings with task specific abilities and thus (inverse) effort. Sorting of individuals into occupations takes this effort function into account and combines it with an occupation specific wage $w_{k}$. In choosing an occupation, individuals are maximizing the wage per unit of effort:

$$
\max _{k}\left(W_{i 1}, \ldots, W_{i K}\right)=w_{k} f_{i k}(n, r)
$$

To see how each individual finds an optimal occupation, equation (3) can be expressed in log terms as

$$
\ln W_{i k}=\ln w_{k}+\phi_{k}(n-r)+r
$$

Since $\phi_{k}$ is increasing in $k$ - that is, the slope of any line with $\phi_{k}>\phi_{k}^{\prime}$ is relatively steeper - there is exactly one occupation not being strictly dominated by another for every individual. With the sorting mechanism as described above, given a certain vector of wages $\left(w_{1}, \ldots, w_{K}\right)$, individual sorting based on equation (4) leads to occupation specific labor supply determined by the joint distribution $g(n, r)$ over individual abilities in the population:

$$
L_{k}^{s}=L_{k}\left(w_{1}, \ldots, w_{K}\right) \quad[k=1, \ldots, K] .
$$

So far little has been said about the occupation specific wages $w_{k}$. In terms of the model, the occupation specific wages will complete the description of the sorting of workers into occupations. In order to determine these equilibrium wage rates $\left(w_{k}, \ldots, w_{K}\right)$, consider the production of the 
final good $\mathrm{Y}$ again. This is produced in Cobb-Douglas fashion with share parameters $\theta_{k}$ determining the "overall importance" of each occupation $k$. Equilibrium then requires:

$$
\frac{w_{k} L_{k}\left(w_{1}, \ldots, w_{K}\right)}{Y}=\theta_{k} \quad[k=1, \ldots, K]
$$

According to equation (6), wages could freely differ across occupations based on different labor supply and variation in the importance of any given occupation for final goods production, for instance. However, as will shortly be seen, for a cut-off occupation - separating home production from offshored activities - in terms of $N$-task intensity to emerge, there has to be some monotonic ordering of wages in terms of $\phi_{k}$. That is, wages either have to monotonically increase or decrease (or be the same) for all $\phi_{k}$. Intuitively, occupations with a relatively high non-routine task intensity should pay higher wages. This could arise in this framework as well. The wage pattern across occupations is determined by demand and supply and a relatively routine intensive occupation will pay a relatively low wage if it commands low prominence in technology and if individual talent distributions are such that a large mass of individuals will select themselves into this occupation. Empirical evidence also seems to point in the same direction. While it is difficult to establish monotonicity, a regression of the average occupation level log wage $\left(\ln w_{k}\right)$ on the average non-routine intensity, $\phi_{k}$, yields a highly significant positive relationship, with a one standard deviation higher $\phi_{k}$ increasing wages by around $12 \%$. Evidence for wages increasing in $\phi_{k}$ is also documented in Ebenstein et al. (2013) and Baumgarten et al. (2013).

To generate such a relationship from the equilibrium in equation (6), it is assumed that the $\theta_{k}$ 's are also increasing in $\phi_{k}$. This seems plausible. Consider the value an additional engineer, designing a new production robot, brings to the production of $Y$ against the additional effect of employing another worker on the factory floor. The increase in output is likely larger in the first case, which would be reflected in a higher $\theta_{k}$ for the engineering occupation. With the assumption of $\theta_{k}$ increasing in $\phi_{k}$, the equilibrium in equation (6) can be obtained either through wages or labor supply increasing with the non-routine intensity of an occupation, or a mixture of both. More formally, it holds that if $\theta_{k} / \theta_{k^{\prime}}>L_{k} / L_{k^{\prime}}$ then $w_{k}>w_{k^{\prime}}$. As argued above, it seems reasonable to assume that $\theta_{k} / \theta_{k^{\prime}}>1$ for $\phi_{k}>\phi_{k^{\prime}}$. A further assumption is to take $L_{k} / L_{k^{\prime}}$ to be smaller than one. If one is willing to assume that the amount of people with the right amount of "talent" in non-routine tasks is decreasing in this amount, there is a decreasing labor supply into higher $\phi_{k}$ occupation at given wages. Now, if wages are higher in higher $\phi_{k}$ jobs, this might make up for the 
extra effort an individual will need when working in that occupation. At this point the increasing wage schedule arises with one additional assumption: If the difference in wages paid by occupation $k$ and $k^{\prime}$ is less than the decline between $k$ and $k^{\prime}$ in population mass selecting themselves into these occupations, the equilibrium in equation (6) is consistent with wages increasing in $\phi_{k}$. Then, $L_{k} / L_{k^{\prime}}<1$ and $\theta_{k} / \theta_{k^{\prime}}>L_{k} / L_{k^{\prime}}$ holds.

All of the above considerations hold without any role for offshoring. To see how offshoring alters the equilibrium sorting, and thus the relative shares of $R$ and $N$-tasks in the economy, consider that offshoring costs are also related to occupational characteristics. In particular, the $N$-intensity of an occupation, $\phi_{k}$, determines the costs of potentially offshoring the occupation to another country, which is denoted by $\beta t(k)$. The structure of these offshoring costs follows Kohler (2004) and Grossman \& Rossi-Hansberg (2008). On the one hand, it has a general component, $\beta$, describing a common cost factor linked to the technological possibilities of conducting certain operations abroad. On the other hand, offshoring costs for each occupation are characterized by the idiosyncratic component, $t(k)$, which is assumed to be increasing in $k$. Hence, the more nonroutine and interactive an occupation is, the more costly its offshore performance will be. This is intuitive as the tasks related to intense communication needs, or tasks which are particularly prone to generating problems that need to be solved in a non-routine manner, are naturally difficult to perform at a distance. In their offshoring decision, firms compare the costs of occupational production across locations Home and Foreign. Due to overall technological disadvantages, wages are assumed to be lower in Foreign. Yet, the relative ordering across occupations is preserved. The same holds true for occupational task requirements.

The result is that wages $w_{k}^{*}$ in Foreign strictly lie below the ones at Home for all occupations. In their decision to offshore firms have to weigh this lower wage against the occupation specific offshoring costs $t(k)$. An occupation is thus offshored only if:

$$
w_{k}>w_{k}^{*} \beta t(k) .
$$

The parallel increasing ordering of occupations, in terms of both wages and offshoring costs, yields one cut-off occupation, $\tilde{k}$, which is the lowest $\phi_{k}$ occupation at home. Observing a cut-off occupation means that $L_{k}\left(w_{1}, \ldots, K\right)=0$ for all $k$ where $w_{k}>w_{k}^{*} \beta t(k)$. This also implies that workers only sort into the occupations with $k \geq \tilde{k}$ since these are the only ones being demanded at home. 
Now, consider an exogenous change in offshoring. The source for an increase in offshoring studied here is the same as in most of the literature and follows Grossman \& Rossi-Hansberg (2008). The idea rests on overall technological progress in terms of information and communication technologies (ICT) reducing the general and common component of offshoring costs, $\beta$, equally for all occupations. Such a fall in $\beta$ makes offshoring less costly for all occupations. Importantly, it could be that it alters the position of the cut-off occupation and thus the range of occupations active in onshore production. ${ }^{7}$ If the fall in $\beta$ is large enough to trigger such an adjustment, the range of occupations performed at home will shrink from $\{\tilde{k}, \ldots, K\}$ to $\left\{\tilde{k}^{\prime}, \ldots, K\right\}$, with $\tilde{k}^{\prime}>\tilde{k}$. This leads to a reallocation of individuals previously employed in occupations $\tilde{k} \leq k<\tilde{k}^{\prime}$ since they are set free, with their optimally chosen occupation no longer in demand at home. Given the sorting rule described by equation (4), these workers will now sort into "the next best" occupation, which is the lowest $\phi_{k}$ one still left at home. From a partial equilibrium perspective, at given wages, this will increase the share of non-routine and interactive tasks performed in the home economy relative to routine and non-interactive ones. ${ }^{8}$ This upward shift in employment shares will also impact on the cost share of tasks. Strictly speaking there is no income paid separately for the two types of tasks, only income paid for separate occupations. Yet, since the non-routine intensity of occupations is increasing in $k$, the share of income paid for non-routine tasks is increasing in $k$ as well. Under the assumption that an occupation's income can be split up into task specific payments by multiplying it with $\phi_{k}$, the cost share of $N$-tasks is the following:

$$
S_{N}^{C}=\frac{\sum_{k} w_{k} L_{k} \phi_{k}}{\sum_{k} w_{k} L_{k}} \quad[k=\tilde{k}, \ldots, K]
$$

With $0 \leq \phi_{k} \leq 1$, the share of $R$-tasks is just $S_{R}^{C}=1-S_{N}^{C}$. Hence, the cost share of $R$-tasks in overall labor cost will fall with an increase in offshoring. This is the main hypothesis being put to the test in the subsequent empirical sections of this paper.

\footnotetext{
${ }^{7}$ Note that with a finite number of occupations it might still be that a small downward shift of $\beta$ does not trigger an expansion of offshoring. Only if the shift is large enough to tip the scale in the trade-off between $k$ and $k+1$ there will be an effect on the range of offshored occupations.

${ }^{8}$ The model used here to inform the estimation in later sections is a partial equilibrium model in the sense that is looks at re-sorting at given wages. In general equilibrium, worker sorting into new occupations is going to affect the wages in these occupations, which will in turn affect the optimal sorting again. An increase in labor supply could lead to a fall in the wage rate leading to more workers switching "up". This inflow of workers into the next higher $\phi_{k}$ occupation again lowers wages there, leading to some individuals switching up out of this job as well. As a results, there could be a general movement of workers up the "occupational latter" leading to more people being employed in higher $\phi_{k}$ occupations. Additionally, increases in output $Y$, due to the cost savings from offshoring, would disproportionately accrue to the higher $\phi_{k}$ jobs as well (through higher $\theta_{k}$ 's). Without fully working out the details, these general equilibrium effects would likely reinforce the partial equilibrium effects.
} 


\section{Data and construction of labor demand variables}

In order to assess the structure of offshoring costs and the related demand shifts in the offshoring process, it has to be clear how tasks are assumed to be bundled into occupations. In the theory outlined in the previous section, there is a number of intermediate inputs, each produced by one occupation through the performance of a specific bundle of tasks. The empirical equivalent to the range of jobs from the model in the previous section is a vector of 74 occupations ordered according to their offshoring costs - the latter being based on their share of $R$-tasks in total tasks. ${ }^{9}$ The task shares within occupations are represented by an average of task intensities at the individual level. For Germany, the best data on this topic comes from the "BIBB/IAB-Employment Survey 1998/99". ${ }^{10}$ This database has previously been used by Spitz-Oener (2006) and Becker et al. (2013), among many others, and has proven to be the source of choice for task related information. The database holds survey-results describing the tasks individual workers perform. It is thus a direct account of observed work contents. This sets the data used here apart from classifications based on external expert assessments of an occupation's typical work content such as the O*NET data base developed for the United States. For the analysis in this paper, 13 different activities are grouped into either $N$-tasks (non-routine and/or interactive) or $R$-tasks (routine and/or noninteractive). ${ }^{11}$ Individual level task intensities are calculated and subsequently aggregated to the 2-digit occupational level as simple mean values. The individual level task intensities are derived as:

$$
\lambda^{i}(k)=\frac{\text { number } N \text {-tasks performed by individual } i \text { in occupation } k}{\text { number of all tasks performed by individual } i \text { in } k}
$$

Averaged within each occupation as $\lambda(k)=\sum \lambda^{i}(k) / L(k)$, the resulting occupation level task scores resemble the measure proposed by Antonczyk et al. (2009). ${ }^{12}$ The measures of task intensities within all 74 occupations considered add up to one and, hence, yield an approximation of how an individual splits her job into different tasks. Naturally, $(1-\lambda(k))$ describes the share of $R$-tasks in total tasks. It is similar to, yet distinct from approaches using category specific intensities such as Spitz-Oener (2006) or Becker et al. (2013), where the number of type- $\tau$ tasks (with

\footnotetext{
${ }^{9}$ These 74 occupations exclude agricultural and military occupations as well as some others such as mining occupations.

${ }^{10}$ The data used is the BIBB/IAB study: "Acquisition and Application of Occupational Qualifications 1998/99", provided to the author by GESIS Cologne, Germany. No. ZA3379. Datafile version 1.0.0, 13.04.2010, doi:10.4232/1.3379.

${ }^{11}$ The grouping is a further aggregation of the five categories in Spitz-Oener (2006), with non-routine analytical, non-routine interactive, and non-routine manual being summarized in the $N$-group with higher costs of offshoring. Routine manual and routine cognitive tasks form the lower cost $R$-group. The individual tasks grouped into these categories are very similar to the ones used in Spitz-Oener (2006). The individual tasks are also listed in the appendix.

${ }^{12}$ The task intensity $\lambda(k)$ is directly and positively related to the theoretical expression $\phi_{k}$. Yet, since this empirical measure holds no capital, it is denoted differently.
} 
$\tau \in$ routine, non - routine) an individual performs is related to all possible type- $\tau$ tasks.

The outcome of the above calculations are occupation level values for task contents, $\lambda(k)$, which derive from how intensively an occupation uses a certain type of task on average. In order to construct industry level task cost and employment shares, these measures are combined with time-varying income and employment data from administrative individual employment records ("BA-Employment Panel") at the occupation level. ${ }^{13}$ These data hold information on the employment of and the total income paid to individuals in a given time period. Crucially, and in contrast to other data sets with smaller dimensions, the data set has a sufficient number of observations to provide for representative distributions of occupational employment and income within 19 out of the 22 2-digit manufacturing industries. This is a crucial element, enabling the use of panel methods to infer the effect of offshoring on relative labor demand for tasks from different within industry movements over time.

A straight forward calculation of the employment share of routine and non-interactive tasks for industry $j, S_{R, j t}^{E}$, is to calculate the employment share of each occupation $k$ in industry $j$ and year $t, \pi^{k j t}$, multiply it with the task scores, $\lambda(k)$ and aggregate this to the industry level. Such calculations are done for 19 manufacturing industries over the time period between 1998 and 2007 at yearly frequency. They look as follows in more formal terms:

$$
S_{R, j t}^{E}=\sum_{k}[1-\lambda(k)] \times \pi^{k j t}
$$

In addition to the straight forward employment shares, cost shares (income weighted employment shares) of $R$-tasks are calculated as well. These will differ from employment shares if wages are systematically higher in relatively $N$-intensive occupations, which is one of the features of the model in section $2 .{ }^{14}$ Calculations of cost shares are done using income information provided in the BA data set. The occupation level task intensities are now multiplied with income shares of occupations within industries, $\omega^{k j t}$. Aggregated to the industry level, this yields the cost share of

\footnotetext{
${ }^{13}$ This study uses the factually anonymous BA-Employment Panel (Years 1998 - 2007). Data access was provided via a Scientific Use File supplied by the Research Data Centre (FDZ) of the German Federal Employment Agency (BA) at the Institute for Employment Research (IAB). For detailed information on the database, see Schmucker \& Seth (2009).

${ }^{14}$ Furthermore, changes in cost shares could arise from general equilibrium effects after offshoring changes that benefit relatively $N$-intensive occupations wages relatively more.
} 
$R$-tasks as:

$$
S_{R, j t}^{C}=\sum_{k}[1-\lambda(k)] \times \omega^{k j t}
$$

It is crucial to note what the above implies in terms of variation used for estimation in this paper. Importantly, all of the variation in relative labor demand measures stems from variations in occupation-industry employment shares or differential wage movements across occupations. This is in line with the related literature, which also uses the between occupation variation when looking at aggregate task changes (see Becker et al. 2013, Kemeny \& Rigby 2012). Note that not only is the variation used here based on the preferred approach in the literature, it is now also consistent with theory as described in section 2, which explicitly considers occupations as fixed bundles of tasks.

The offshoring intensities for each industry and year are calculated using a method similar to Feenstra \& Hanson (1999). In particular, the measures are constructed to represent the share of imported intermediate inputs in total industry output - a slight variation of the original measure following Geishecker (2006). The necessary data on input-use by both industry and year are taken from the import matrices that are part of the input-output tables provided by the Statistical Office of Germany. It is important to note that only inputs which originate in the same foreign industry $j^{*}$ as the home industry $j$ are included. Thereby it is ruled out that traditionally imported intermediates, that do not reflect an offshoring decision, are counted in. This makes the offshoring indices constructed here resembling the "narrow" measure of Feenstra \& Hanson (1999): ${ }^{15}$

$$
O F F_{j t}=\frac{I M P_{j t} \times \Omega_{j^{*} j t}}{Y_{j t}}
$$

$\Omega_{j^{*} j t}$ represents the share of imports from a specific industry $j^{*}$ used in the same industry $j$ at home. $I M P_{j}$ measures all imports of industry $j .{ }^{16}$ These imports can be split in order to differentiate among different offshoring destinations. To provide for the closest fit with theory-based offshoring considerations, which are rooted in labor cost differentials across countries, a non-OECD country specific offshoring intensity is calculated to complement the worldwide measure. This region specific calculation entails the assumption that $\Omega_{j^{*} j t}$ does not differ across country groups, an assumption which is frequently taken in the empirical offshoring literature (see Geishecker 2006).

\footnotetext{
${ }^{15}$ An alternative specification would be to use the share of intermediate inputs from all foreign industries. This variant is called "wide" in Feenstra \& Hanson (1999).

${ }^{16}$ These trade data are taken from the OECD STAN database. See the appendix for details.
} 
$Y_{j t}$ is the industry $j$ 's output in year $t$ as supplied by the OECD in the STAN data base. ${ }^{17}$

Table 1 gives an overview of the constructed variables. Offshoring intensities vary substantially between industries and over time, with most industries showing an increase over the sample period. Offshoring to non-OECD countries is much less important from a levels perspective, yet, it does show much stronger growth and has increased for all considered industries. It is of no surprise to observe relatively high offshoring intensities in the wearing and apparel and textile industries as well as in basic metals. This holds true for both worldwide and non-OECD offshoring. The highest growth is found in the radio, television and communication industry. At the same time, the cost share of routine and non-interactive tasks fell in most industries. Employment shares also fell, but are excluded from this table due to expositional reasons. Employment shares of routine and non-interactive tasks are slightly higher. This is intuitive since using employment shares is equivalent to assuming equal wages across occupations. With $R$-tasks intensive occupations being rewarded at a lower wage, the industry level wage cost share of these tasks is lower compared to their employment share. While falling relative labor demand in the face of increased offshoring intensities point to a possible relationship between the variables, it will be left to the empirical analysis in the following sections to uncover the strength and significance of this link.

\footnotetext{
${ }^{17}$ Using output, which is equivalent to value added plus inputs, has the advantage of better accounting for domestic outsourcing. If firms outsource inputs domestically, the input measure will rise but this increase will be counterbalanced by a decrease in value added.
} 
Table 1: Descriptives: offshoring and task intensity

\begin{tabular}{|c|c|c|c|c|c|c|c|c|c|}
\hline \multirow[t]{2}{*}{ industry name } & \multicolumn{3}{|c|}{ offshoring world } & \multicolumn{3}{|c|}{ offshoring non-OECD } & \multicolumn{3}{|c|}{ cost share of $R$-tasks } \\
\hline & 1998 & 2007 & change & 1998 & 2007 & change & 1998 & 2007 & change \\
\hline Food Products And Beverages & 2.93 & 3.96 & 1.03 & 0.44 & 0.83 & 0.39 & 37.56 & 38.76 & 1.21 \\
\hline Textiles & 10.19 & 8.90 & -1.30 & 3.84 & 5.12 & 1.28 & 46.45 & 44.34 & -2.11 \\
\hline Wearing Apparel; Dressing & 16.55 & 13.48 & -3.07 & 6.23 & 7.66 & 1.43 & 32.09 & 24.75 & -7.34 \\
\hline Wood Products, Except Furniture & 4.36 & 3.68 & -0.67 & 0.89 & 1.24 & 0.35 & 45.79 & 45.66 & -0.12 \\
\hline Pulp, Paper And Paper Products & 8.87 & 8.64 & -0.22 & 0.43 & 1.28 & 0.84 & 45.17 & 46.48 & 1.31 \\
\hline Publishing, Printing & 0.08 & 0.88 & 0.80 & 0.00 & 0.08 & 0.07 & 34.57 & 29.89 & -4.67 \\
\hline Chemicals And Chemical Products & 10.69 & 13.93 & 3.24 & 0.73 & 1.20 & 0.46 & 35.04 & 34.22 & -0.81 \\
\hline Rubber And Plastic Products & 0.89 & 1.67 & 0.77 & 0.08 & 0.23 & 0.15 & 48.23 & 47.79 & -0.45 \\
\hline Other Non-metallic Mineral Products & 2.06 & 2.06 & 0.01 & 0.20 & 0.41 & 0.21 & 43.44 & 42.58 & -0.86 \\
\hline Basic Metals & 12.58 & 17.39 & 4.81 & 2.06 & 4.72 & 2.66 & 49.34 & 50.82 & 1.48 \\
\hline Fabricated Metal Prod., excl. Mach. & 1.37 & 1.65 & 0.29 & 0.23 & 0.43 & 0.20 & 46.84 & 47.28 & 0.44 \\
\hline Machinery And Equipment NEC & 5.66 & 7.95 & 2.29 & 0.97 & 2.24 & 1.27 & 40.80 & 39.06 & -1.74 \\
\hline Office Machinery And Computers & 9.64 & 13.47 & 3.82 & 2.38 & 7.41 & 5.03 & 25.47 & 21.24 & -4.24 \\
\hline Electrical Machinery & 5.29 & 6.89 & 1.60 & 0.91 & 1.53 & 0.63 & 36.84 & 35.70 & -1.14 \\
\hline Radio, Television, Communication & 4.50 & 19.01 & 14.51 & 1.05 & 9.02 & 7.98 & 31.95 & 28.98 & -2.96 \\
\hline Medical, Precision And Optical & 4.07 & 5.17 & 1.09 & 0.61 & 1.00 & 0.39 & 33.36 & 32.04 & -1.31 \\
\hline Motor Vehicles, Trailers & 6.42 & 9.24 & 2.82 & 0.19 & 0.60 & 0.41 & 44.61 & 41.71 & -2.91 \\
\hline Other Transport Equipment & 7.36 & 10.03 & 2.67 & 0.33 & 1.24 & 0.90 & 37.10 & 33.35 & -3.74 \\
\hline Furniture; Manufacturing NEC & 6.80 & 8.78 & 1.98 & 2.00 & 3.95 & 1.96 & 42.59 & 41.23 & -1.36 \\
\hline
\end{tabular}

Notes: The table shows the offshoring intensities for all industries included in the sample - both for worldwide offshoring and non-OECD country offshoring. Offshoring is the share of intermediate inputs (originating from the same industry abroad) in industry output. It also shows the cost shares which are calculated as total wage bill of routine and non-interactive tasks (occupation wage-sum multiplied by tasks intensity) over total wages. All values are expressed in \%. Changes are simple differences. Some industry names are abbreviated.

\section{Does offshoring affect relative labor demand for tasks?}

\subsection{Estimation set-up}

The estimation set-up seeks to test the main hypothesis from the theory in section 2: It should uncover how offshoring is linked to changes in the task composition within industries. The empirical analysis takes the main insights from the model to build a reduced-form relationship between these key variables. It is reduced-from in that it treats output and capital as fixed in the short-run and thus abstracts from some potential general equilibrium effects offshoring might have on these variables. This seems valid in the sense that the period under study comprises ten years only. Given the short-run perspective, the estimation resembles those in Feenstra \& Hanson (1996), Berman et al. (1994), and Becker et al. (2013), yet it derives from a different theoretical fundament that better matches the task perspective. ${ }^{18}$ The cost share (or employment share in some variations) of routine and non-interactive tasks as dependent variable is regressed on the logarithm of the industry's capital intensity and the logarithm of its output (which is real output in its role as a control-variable), capturing that the effect of offshoring is conditional on output and capital -

\footnotetext{
${ }^{18}$ What additionally is missing from the model in comparison is the relative wage term between factors since tasks are explicitly not treated as separate factors independently supplied to production due to the bundling assumption.
} 
a direct implication of the short-run perspective. Offshoring is included not in log-form but as the share of imported intermediates as defined in equation (12). Just as in Feenstra \& Hanson (1996), offshoring acts as a shift variable of relative labor demand. In a slight deviation from the theory, a further shift variable, research and development spending as a share in value added, is admitted to affect the cost share in the preferred specification. The values are collected in $Z_{j t}$. Including the research and development variable, as an approximation to technological advances, might also help to rule out biased coefficient due to the correlation of technology and relative labor demand for tasks. In particular, Liu \& Trefler (2011) stress that it should be included as a separate regressor in any model linking offshoring and the labor market. The unobserved variation in the estimation equation is assumed to be captured by the composite term $\nu_{j t}=\delta_{t}+\mu_{j}+u_{j t}$. Part of this unobserved variation can be controlled for using fixed effects for year $\left(\delta_{t}\right)$ and industry $\left(\mu_{j}\right)$, which control for economy wide trends and industry specific time-invariant characteristics, respectively. ${ }^{19}$ The remaining part of unobserved variation $\left(u_{j t}\right)$ is assumed to be uncorrelated with any included variable and thus the standard independent error term in the equation. Standard errors are clustered at the industry level. ${ }^{20}$ Taken together, the following estimation equation for the cost share of routine and non-interactive tasks in industry $j$ at time $t$ is used:

$$
S_{r, j t}^{C}=\gamma_{1} O F F_{j t}+\gamma_{2} \ln Y_{j t}+\gamma_{3} \ln (K / Y)_{j t}+\gamma Z_{j t}+\mu_{j}+\delta_{t}+u_{j t}
$$

With a suitable framework for estimation at hand, it can be investigated whether and to what extend offshoring shifts the relative labor demand for tasks. The next subsection opens with the presentation of regressions based on cost and employment shares of $R$-tasks in total tasks. Subsequently, the effect of offshoring on relative task demand will be estimated controlling for the industry level skill composition - thus answering whether there are indeed additional insights to be gained from using a task-based approach. A discussion of the robustness of the results to possible endogeneity issues, to adjustment of standard errors and inference with few clusters, and to data alterations completes the empirical analysis.

\footnotetext{
${ }^{19}$ An alternative approach do dealing with constant and industry specific components of the composite error term would be to first-difference the data. However, given that the main variables in the model are calculated from a variety of sources, there is some scope for measurement error on a year-to-year basis. According to Griliches \& Hausman (1986), the fixed effects estimator is better able to deal with measurement error and is thus the preferred model in nearly the entire related literature and in this study.

${ }^{20}$ See subsection 4.4 for a discussion of the appropriate handling of inference with few clusters.
} 


\subsection{Estimation results}

Table 2 shows the outcome of estimating model (13) for both cost and employment shares of routine and non-interactive tasks, $S_{R, j t}^{C}$ and $S_{R, j t}^{E}$, respectively. In the first column, results are presented from estimating equation (13) for cost shares with only output and capital intensity included as further determinants of relative labor demand. This baseline specification already reveals the main result, which is hardly changed in further specifications: An increase in offshoring reduces the relative labor demand for routine and non-interactive tasks. The results indicate that, on average, a one percentage point increase in the offshoring intensity (worldwide) leads to a fall of 0.06 percentage points in the $R$-task intensity. This finding is derived upon the inclusion of industry and year fixed effects controlling for common trends as well as time-invariant heterogeneity across industries. The effect is statistically significant at the $5 \%$ level. Taking a look at the results in column 2, it becomes evident that - as expected due to the cost savings motive in, and thus a closer resemblance to, common offshoring models - the effect of offshoring to non-OECD countries is higher, with a one percentage point rise in offshoring shrinking the demand for routine and non-interactive tasks by 0.39 percentage points. The inclusion of the research and development intensity as a control for task shifts related to technological change does not alter the result on offshoring much. Note, however, that only differential movements in this variable across industries are picked up here, as all economy wide time trends and industry specific time-constant factors are already controlled for in the estimation. The coefficient on the R\&D intensity is positive and significant. At first sight this may seem surprising since studies looking at relative labor demand in terms of skill categories usually find negative coefficients with mixed significance. Note, however, that the task categories here do not necessarily lead to expect the same result. While most R\&D tasks are performed by high-skilled employees, these tasks could also be characterized by low interactivity and some routine steps - characteristics that enable offshoring. In columns 5 and 6 , results arising from using employment shares are shown. Reassuringly, these are similar to the cost share results hinting at the effect working through shifts in occupational employment - shifts away from occupations relatively intensive in routine and non-interactive tasks.

The coefficients from the preceding estimations permit a look at the economic relevance of the results. Using the estimates from column 3 in table 2, it emerges that a one percentage point increase in worldwide offshoring decreases the relative labor demand for R-tasks by 0.064 percentage points. The total output weighted average decline in the cost share of routine and non- 
Table 2: Baseline regressions for cost and employment shares

\begin{tabular}{|c|c|c|c|c|c|c|}
\hline & 1 & 2 & 3 & 4 & 5 & 6 \\
\hline & \multicolumn{4}{|c|}{ cost share of $R$-tasks } & \multicolumn{2}{|c|}{ emp. share of $R$-tasks } \\
\hline offshoring intensity & $\begin{array}{r}-0.0624^{* *} \\
(0.0235)\end{array}$ & & $\begin{array}{r}-0.0640 * * \\
(0.0224)\end{array}$ & & $\begin{array}{r}-0.0520^{* *} \\
(0.0185)\end{array}$ & \\
\hline offshoring intensity to non-OECD & & $\begin{array}{r}-0.3935^{* * *} \\
(0.1221)\end{array}$ & & $\begin{array}{r}-0.3654^{* * *} \\
(0.1099)\end{array}$ & & $\begin{array}{r}-0.3395^{* * *} \\
(0.0883)\end{array}$ \\
\hline $\ln \left(Y_{j t}\right)$ & $\begin{array}{r}0.0143 \\
(0.0294)\end{array}$ & $\begin{array}{r}0.0141 \\
(0.0236)\end{array}$ & $\begin{array}{r}0.0280 \\
(0.0314)\end{array}$ & $\begin{array}{r}0.0229 \\
(0.0263)\end{array}$ & & $\begin{array}{r}0.0177 \\
(0.0220)\end{array}$ \\
\hline $\ln \left(K_{j t} / Y_{j t}\right)$ & $\begin{array}{r}0.0167 \\
(0.0237)\end{array}$ & $\begin{array}{r}0.0016 \\
(0.0186)\end{array}$ & $\begin{array}{r}0.0219 \\
(0.0259)\end{array}$ & $\begin{array}{r}0.0062 \\
(0.0207)\end{array}$ & $\begin{array}{r}-0.0003 \\
(0.0107)\end{array}$ & $\begin{array}{r}0.0029 \\
(0.0156)\end{array}$ \\
\hline R\&D intensity & & & $\begin{array}{r}0.0985^{* *} \\
(0.0443)\end{array}$ & $\begin{array}{r}0.0657 \\
(0.0416)\end{array}$ & $\begin{array}{r}0.0638^{* *} \\
(0.0225)\end{array}$ & $\begin{array}{r}0.0616^{*} \\
(0.0355)\end{array}$ \\
\hline Observations & 190 & 190 & 190 & 190 & 190 & 190 \\
\hline R-squared & 0.4488 & 0.5188 & 0.4786 & 0.5316 & 0.3990 & 0.4852 \\
\hline Number of sectors & 19 & 19 & 19 & 19 & 19 & 19 \\
\hline
\end{tabular}

Notes: The dependent variable is the industry level cost or employment share of $R$-tasks. Cluster-robust standard errors are in parentheses. ${ }^{* * *},{ }^{* *}$, and ${ }^{*}$ indicate significance at $1 \%, 5 \%$, and $10 \%$, respectively. All regressions control for industry and year fixed effects. The sample consists of 19 industries over 10 years (1998-2007).

interactive tasks was about 1.8 percentage points over the sample period. Worldwide offshoring increased by around 2.7 percentage points, or $47 \%$ of its initial value. Thus, worldwide offshoring accounts for about 10 percent of this total decline in the cost share of $R$-tasks. Offshoring to non-OECD destinations shows an increase by 1.2 percentage points, more than a doubling over the sample period. Using the above estimate of $\hat{\gamma}_{1}=-0.3654$ from column 4 of table 2 , the equivalent number of the share of explained variation in relative labor demand for routine and non-interactive tasks stands at $23.89 \%$. This type of offshoring is thus able to explain a considerable part - up to almost one fourth - of the observed shift in relative labor demand for tasks.

\subsection{Estimations controlling for skill composition}

Thus far the innovative nature of a task-based approach has simply been stated. It may well be that the routine and non-interactive characterization of occupations and the corresponding industry level task intensities simply reflect the same fault lines as the high-skilled vs. low-skilled dichotomy always did. Relabeling an old phenomenon would hardly constitute a contribution to the literature. Therefore, the next step is to test for shifts in relative labor demand while explicitly controlling for the industry level skill composition, following an idea put forth in Becker et al. (2013). Table 3 shows the outcome of this important exercise. The first two columns show the familiar results without skill share controls for comparison. The further columns include control for shifts in the share of highly skilled individuals (tertiary education) and medium-skilled (vocational training education) individuals, respectively. While the high-skill versus low-skill distinction has 
a long history in the literature, recent papers have stressed that individuals in the middle of the skill distribution are mostly engaged in routine and non-interactive tasks (see Acemoglu \& Autor 2011). It thus seems necessary to check what the inclusion of these skill shares does to the effect of offshoring on relative labor demand for tasks. The result is reassuring. Again, offshoring is found to shift relative labor demand in favor of non-routine and interactive tasks. The result furthermore shows a similar robustness as the baseline analysis did. Crucially, the estimated coefficient on the offshoring variable is still negative and statistically significant in all variations, albeit slightly reduced in magnitude. Taking a look at offshoring induced shifts in relative labor demand from a task perspective thus adds information beyond what the skill-based view is able to explain. Within education-based skill groups, the task dimension seems to be a relevant source of heterogeneity. This is a result in line with Baumgarten et al. (2013), where occupation specific wage effects are found to be present within skill groups, or Crinò (2010), where labor demand elasticities are heterogeneous across occupations within skill groups, according to how intensive they are in tasks showing relatively more tradable characteristics.

Table 3: Cost share regression with skill share controls

\begin{tabular}{|c|c|c|c|c|c|c|}
\hline cost share of $R$-tasks & 1 & 2 & 3 & 4 & 5 & 6 \\
\hline offshoring intensity & $\begin{array}{r}-0.0640^{* *} \\
(0.0224)\end{array}$ & & $\begin{array}{r}-0.0544^{* *} \\
(0.0255)\end{array}$ & & $\begin{array}{c}-0.0501^{*} \\
(0.0280)\end{array}$ & \\
\hline offshoring intensity to non-OECD & & $\begin{array}{r}-0.3654^{* * *} \\
(0.1099)\end{array}$ & & $\begin{array}{r}-0.2842^{* * *} \\
(0.0877)\end{array}$ & & $\begin{array}{r}-0.3001^{* *} \\
(0.1188)\end{array}$ \\
\hline $\ln \left(Y_{j t}\right)$ & $\begin{array}{r}0.0280 \\
(0.0314)\end{array}$ & $\begin{array}{r}0.0229 \\
(0.0263)\end{array}$ & $\begin{array}{r}0.0564^{* *} \\
(0.0234)\end{array}$ & $\begin{array}{c}0.0510^{* *} \\
(0.0199)\end{array}$ & $\begin{array}{r}0.0280 \\
(0.0269)\end{array}$ & $\begin{array}{r}0.0240 \\
(0.0232)\end{array}$ \\
\hline $\ln \left(K_{j t} / Y_{j t}\right)$ & $\begin{array}{r}0.0219 \\
(0.0259)\end{array}$ & $\begin{array}{r}0.0062 \\
(0.0207)\end{array}$ & $\begin{array}{r}0.0398^{* *} \\
(0.0179)\end{array}$ & $\begin{array}{c}0.0269^{*} \\
(0.0141)\end{array}$ & $\begin{array}{r}0.0062 \\
(0.0185)\end{array}$ & $\begin{array}{r}-0.0058 \\
(0.0165)\end{array}$ \\
\hline R\&D intensity & $\begin{array}{r}0.0985^{* *} \\
(0.0443)\end{array}$ & $\begin{array}{r}0.0657 \\
(0.0416)\end{array}$ & $\begin{array}{r}0.0165 \\
(0.0307)\end{array}$ & $\begin{array}{r}-0.0062 \\
(0.0237)\end{array}$ & $\begin{array}{r}0.0850^{* *} \\
(0.0382)\end{array}$ & $\begin{array}{r}0.0588^{*} \\
(0.0287)\end{array}$ \\
\hline share of high-skilled & & & $\begin{array}{r}-1.1344^{* * *} \\
(0.1717)\end{array}$ & $\begin{array}{r}-1.0925^{* * *} \\
(0.1554)\end{array}$ & & \\
\hline share of medium-skilled & & & & & $\begin{array}{r}0.3581^{* * * *} \\
(0.0938)\end{array}$ & $\begin{array}{r}0.3379^{* * *} \\
(0.0875)\end{array}$ \\
\hline Observations & 190 & 190 & 190 & 190 & 190 & 190 \\
\hline R-squared & 0.4786 & 0.5316 & 0.7703 & 0.7988 & 0.6171 & 0.6535 \\
\hline Number of sector & 19 & 19 & 19 & 19 & 19 & 19 \\
\hline
\end{tabular}

Notes: The dependent variable is the industry level cost share of $R$-tasks. Cluster-robust standard errors are in parentheses. ${ }^{* * *},{ }^{* *}$, and ${ }^{*}$ indicate significance at $1 \%, 5 \%$, and $10 \%$, respectively. All regressions control for industry and year fixed effects. The sample consists of 19 industries over 10 years (1998-2007). High-skilled is defined as having tertiary education; low-skilled otherwise. Medium-skilled is defined as having a vocational training education versus either a tertiary degree or no vocational training. 


\subsection{Robustness of the results}

\subsubsection{Discussion of possible endogeneity}

The above results represent correlations between industry level offshoring fluctuations and relative labor demand for tasks. They represent a confirmation of the predictions arising from the theory presented in section 2. Furthermore, the integration of large emerging economies like China into world markets in the time period considered can arguably be regarded as an exogenous process from the perspective of German industry level relative labor demand. However, there is no direct claim that the results are necessarily to be interpreted in a causal way. Nevertheless, this section carefully discusses the underlying assumption of exogeneity of the offshoring measures and confirms the significant link between offshoring and relative labor demand for tasks using an instrumental variable strategy.

The assumption of exogeneity of the offshoring variables may be called into question if one thinks about industry level technology shocks that could affect both, relative labor demand and offshoring. However, the results presented so far already account for some of these potential influences. By controlling for industry fixed effects, general technological differences between industries that do not vary over time are no longer an issue. Neither are technological developments that affect all industries in the same way since these common trends are captured by the year fixed effects. Some time varying industry specific influences are measured through the R\&D expenditure shares and the capital output ratios. Together, the above should control for a lot of variation possibly induced by technology shocks. The scope for bias thus seems limited, yet, it is not completely impossible that some disturbance remains. In addition to the argument around industry specific technology shocks, Wright (2012) has recently discussed the possibility of reverse causality in the offshoring context. The idea behind this source of bias is that changes in labor market variables could trigger lobbying activities from groups most severely affected. These protectionist measures could in turn impact on the trade-based offshoring measures. In the present context this issue appears less problematic since labor interests are generally not organized along task lines - in particular since the task dimension cuts right through the skill dimension in many cases. While ameliorating some concerns, neither of the above arguments are able to completely rule out endogeneity of the offshoring measures, however. In the following, a possible instrumental variable strategy is thus discussed. 
Table 4: Cost share regression with instrumental variables

\begin{tabular}{|c|c|c|}
\hline cost share of $R$-tasks & 1 & 2 \\
\hline & \multicolumn{2}{|c|}{ U.S. import penetration as IV } \\
\hline offshoring intensity & $\begin{array}{c}-0.7653^{*} \\
(0.4062)\end{array}$ & \\
\hline offshoring intensity to non-OECD & & $\begin{array}{r}-1.1753^{* * *} \\
(0.4557)\end{array}$ \\
\hline $\ln \left(Y_{j t}\right)$ & $\begin{array}{r}0.0858 \\
(0.0541)\end{array}$ & $\begin{array}{r}0.0232 \\
(0.0287)\end{array}$ \\
\hline $\ln \left(K_{j t} / Y_{j t}\right)$ & $\begin{array}{r}0.0229 \\
(0.0297)\end{array}$ & $\begin{array}{r}-0.0284 \\
(0.0314)\end{array}$ \\
\hline R\&D intensity & $\begin{array}{r}0.1218 \\
(0.0888)\end{array}$ & $\begin{array}{r}-0.0025 \\
(0.0768)\end{array}$ \\
\hline Observations & 190 & 190 \\
\hline Number of sector & 19 & 19 \\
\hline First stage F-statistic & 5.79 & 14.38 \\
\hline Underidentification test $\left(\chi^{2}\right)$ & 4.144 & 4.907 \\
\hline$p$-value & 0.0418 & 0.0268 \\
\hline Endogeneity test $\left(\chi^{2}\right)$ & 3.303 & 3.224 \\
\hline$p-$ value & 0.0691 & 0.0726 \\
\hline
\end{tabular}

Notes: The dependent variable is the industry level cost share of $R$-tasks. Cluster-robust standard errors are in parentheses. $^{* * *},{ }^{* *}$, and ${ }^{*}$ indicate significance at $1 \%, 5 \%$, and $10 \%$, respectively. All regressions control for industry and year fixed effects in both stages.

An important idea in this context that has recently been introduced to the offshoring literature is to instrument offshoring in one industry with offshoring in that same industry in another country or region (Autor et al. 2013, Geishecker \& Görg 2013). The argument for such a strategy is that offshoring trends in different countries are driven by the same global factors - factors closely related to a fall in the general offshoring $\operatorname{costs} \beta$. If this constitutes a good and valid instrument, the correlation between offshoring in the same industry across countries would be sufficiently high, while offshoring in the other country would not directly impact on relative labor demand for tasks in the country originally under study. However, the assumption of no correlation between offshoring in one country and labor market variables in another also raises doubts. In competitive international markets, spillovers through shifts in markets shares of internationally active firms seem likely, all the more so in a border-less European Union. One option is to use a values from a country outside the European Union but still similar in its offshoring exposure to reduce these spillovers - the United States for example. In table 4, import penetration ratios from U.S. industries are used as instruments for German industry level offshoring. Import penetration is used since this more general measure likely captures some of the same global influences and is readily and reliably available from the OECD STAN data base for the United States. The first stage $F$-statistics are within the range of what is usually considered necessary for non-OECD offshoring 
while being slightly below for the worldwide measure. Tests for underidentification support the chosen instruments. The results show larger coefficients than before that are statistically different from both zero and the previous fixed effects results. Conditional on the IV strategy being valid, the effect of offshoring on relative labor demand for tasks would thus even be stronger. In any case, previous results would not be biased upward and the direction and significance of link between offshoring and task shifts receives further support.

\subsubsection{Inference with few clusters}

Recently, Cameron et al. (2008) have voiced concerns about inference in empirical settings with clustered standard errors when the number of clusters is small. Their suggestion is to use a cluster wild-bootstrap- $t$ procedure that provides an asymptotic refinement. This research has made an impact on some empirical studies in the last years. However, the study by Cameron et al. (2008) is careful enough to point out that their results are derived from simulations conducted in certain settings. It provides a detailed discussion on how well cluster robust standard errors perform relative to different bootstrap-se and bootstrap- $t$ methods - always in relation to varying numbers of clusters. While they generally favor the wild-bootstrap- $t$ procedure in most settings using micro level data, their results do not imply its use is mandatory for all possible settings with few clusters. With respect to the setting in this paper, where the analysis features 19 clusters (industries), one important results stands out. Simulations conducted by Cameron et al. (2008), with data from Bertrand et al. (2004), which have a similar setting to the one used here, building on aggregate level measures over time, reveal the performance of cluster robust standard errors not to be significantly outperformed by any bootstrap procedure for 20 clusters. Only when reducing the number of clusters below 10, some bootstrap methods outperform the ones based on cluster robust standard errors. The procedure used in the preceding estimations presented here - implementing cluster robust standard errors - thus implicitly receives support from the study by Cameron et al. (2008). Yet, in order to deliver an alternative to cluster robust inference, the main regressions for the cost share of $R$-tasks are re-run using a wild bootstrap- $t$ procedure. Reassessing the main model, as in columns 3 and 4 of table 2 , statistical significance is always preserved at conventional levels. ${ }^{21}$

\footnotetext{
${ }^{21}$ The implementation was done via the user written STATA ado-command "cgmwildboot" provided by Judson Caskey at https://webspace.utexas.edu/jc2279/www/data.html. It was run with 1000 repetitions and a null hypothesis of zero imposed for the offshoring variables and the controls. Instead of using industry fixed effects as binary regressors, which is infeasible in this setting, the data are de-meaned using xtdata before running cgmwildboot, which may be suboptimal. Year effects are included as well as the control variables from the previous analyses: $\ln \left(Y_{j t}\right), \ln \left(K_{j t} / Y_{j t}\right)$, and R\&D intensity.
} 


\subsubsection{Data alterations}

Table 5: Robustness, cost share regressions

\begin{tabular}{|c|c|c|c|c|c|}
\hline & 1 & 2 & 3 & 4 & 5 \\
\hline & $1999-2006$ & exclude ind. 32 & exclude ind. 18 & Spitz-Oener Tasks & Geishecker Offshoring \\
\hline offshoring intensity to non-OECD & $\begin{array}{r}-0.4748^{* * *} \\
(0.1113)\end{array}$ & $\begin{array}{r}-0.4027^{* *} \\
(0.1616)\end{array}$ & $\begin{array}{r}-0.2617^{* * *} \\
(0.0690)\end{array}$ & $\begin{array}{r}-0.4130^{* * *} \\
(0.1421)\end{array}$ & $\begin{array}{r}-1.0410^{* * *} \\
(0.1962)\end{array}$ \\
\hline $\ln \left(Y_{j t}\right)$ & $\begin{array}{r}0.0197 \\
(0.0193)\end{array}$ & $\begin{array}{r}0.0242 \\
(0.0329)\end{array}$ & $\begin{array}{r}-0.0038 \\
(0.0169)\end{array}$ & $\begin{array}{r}0.0149 \\
(0.0180)\end{array}$ & $\begin{array}{r}-0.0256 \\
(0.0157)\end{array}$ \\
\hline $\ln \left(K_{j t} / Y_{j t}\right)$ & $\begin{array}{r}-0.0140 \\
(0.0141)\end{array}$ & $\begin{array}{r}0.0054 \\
(0.0274)\end{array}$ & $\begin{array}{r}-0.0042 \\
(0.0194)\end{array}$ & & $\begin{array}{r}-0.0175 \\
(0.0165)\end{array}$ \\
\hline R\&D intensity & $\begin{array}{r}0.0494^{* *} \\
(0.0219)\end{array}$ & $\begin{array}{c}0.0843^{*} \\
(0.0406)\end{array}$ & $\begin{array}{r}0.0385 \\
(0.0376)\end{array}$ & $\begin{array}{r}-0.0125 \\
(0.0395)\end{array}$ & $\begin{array}{r}0.0111 \\
(0.0535)\end{array}$ \\
\hline Observations & 152 & 180 & 180 & 190 & 119 \\
\hline $\mathrm{R}$-squared & 0.6375 & 0.4944 & 0.5279 & 0.5373 & 0.6226 \\
\hline Number of sector & 19 & 18 & 18 & 19 & 17 \\
\hline
\end{tabular}

Notes: The dependent variable is the industry level cost share of $R$-tasks. Cluster-robust standard errors are in parentheses. ${ }^{* *},{ }^{* *}$, and ${ }^{*}$ indicate significance at $1 \%, 5 \%$, and $10 \%$, respectively. All regressions control for industry and year fixed effects. In the last column offshoring is to Asian countries and not to all non-OECD countries since this distinction was not available in the alternative data provided by Ingo Geishecker (http://www. uni-goettingen. de/en/99958.html) available until 2004 and for 17 of the industries used here.

Further doubts regarding the robustness of the results are dispelled by numerous alterative specifications. Table 5 looks at the offshoring intensity to non-OECD countries, since this is the concept of offshoring most closely related to the theoretical considerations and to improve the exposition. ${ }^{22}$ It holds results for a shorter sample span (1999-2006), for reduced samples, in which the industries with the largest increase in offshoring (32) and the largest decrease in R-task intensity (18) are dropped, for cost shares of tasks constructed with task measures as in Spitz-Oener (2006), and finally for alternative measures of offshoring regarding the sources (Geishecker 2006). The main message of this paper remains unaltered: Offshoring remains a significant and strong factor in the decline of relative labor demand for routine and non-interactive tasks.

\section{Conclusion}

Since trade is becoming more of a task-related phenomenon due to the increase in offshoring activities by firms, the pattern of effects across workers is changing as well. In particular, the skillbased characterization of differentially affected groups falls short of comprehensively capturing the effects. Offshoring occurs based on relocation cost for single occupations, which do not necessarily reflect skill intensities. This paper takes an industry perspective and puts this claim to a test by

\footnotetext{
${ }^{22}$ The results for worldwide offshoring show a similar robustness. The coefficients are very similar in magnitude to the ones from previous sections and are still statistically significant, the only exemption being the model without sector $32(p$-value $=0.167)$.
} 
analyzing relative labor demand from a task perspective.

First, a model is developed to describe the mechanisms underlying the link between offshoring and shifts in employment and cost shares of tasks. This model explicitly treats occupations as fixed bundles of tasks which are, as a whole, subject to the offshoring decision. This is a crucial difference to skill-based approaches, in which individuals either supply high-skilled or low-skilled labor. Furthermore, the model highlights the between-occupation dimension in task share changes in the economy. The model introduces a sorting mechanism of individuals across occupations, which relies on a trade-off between occupations specific wages and individual abilities in terms of effort needed for the execution of certain tasks. In such a setting, an overall fall in offshoring costs can shift the cut-off occupation, which separates home from foreign production, such that the range of occupations at home shrinks. Crucially, the remaining occupations are characterized by a higher non-routine and interactive task content. Since workers whose jobs have gone offshore re-sort into these occupations, average employment shares and cost shares of routine and non-interactive tasks fall in the home economy.

Second, the theoretical predictions are tested and new evidence on the link is provided using industry level data from German manufacturing. A clear and robust result emerges. An increase in offshoring significantly reduces home country relative demand for routine and non-interactive tasks - in particular if this offshoring is directed towards non-OECD countries. The additional value compared to skill related measures is demonstrated by the fact that this demand shift is also observed when controlling for the skill composition of industries. The main results show offshoring to account for between about $10 \%$ and about $23 \%$ of the observed "task-upgrading" over the period 1998-2007.

An important message of this study - and one that does not directly emerge from models such as Grossman \& Rossi-Hansberg (2008) - is that between-occupation re-allocations are a common response to offshoring. This is an important insight for policy makers concerned with designing a policy framework that provides the necessary flexibility in this adjustment process.

\section{References}

Acemoglu, D. \& Autor, D. (2011), Skills, Tasks and Technologies: Implications for Employment and Earnings, in O. Ashenfelter \& D. Card, eds, 'Handbook of Labor Economics', Vol. 4, Elsevier, North Holland/NL, pp. 1043-1171.

Antonczyk, D., Fitzenberger, B. \& Leuschner, U. (2009), 'Can a Task-Based Approach Explain the Recent Changes in the German Wage Structure?', Journal of Economics and Statistics / Jahrbücher für Nationlalökonomie und Statistik 229(2-3), 214-238. 
Autor, D. H., Dorn, D. \& Hanson, G. H. (2013), 'The China Syndrome: Local Labor Market Effects of Import Competition in the United States', American Economic Review . forthcoming.

Autor, D. H. \& Handel, M. (2013), 'Putting Tasks to the Test: Human Capital, Job Tasks and Wages', Journal of Labor Economics . forthcoming.

Autor, D. H., Katz, L. F. \& Kearney, M. S. (2006), 'The Polarization of the U.S. Labor Market', American Economic Review PEPP 96(2), 189 - 194.

Autor, D., Levy, F. \& Murnane, R. (2003), 'The Skill Content of Recent Technological Change: An Empirical Exploration', Quarterly Journal of Economics 118(4), 1279-1333.

Baldwin, R. (2006), Globalisation: The Great Unbundling(s), in 'Globalisation Challenges for Europe', Secretariat of the Economic Council, Finnish Prime Minister's Office, chapter 1.

Baumgarten, D., Geishecker, I. \& Görg, H. (2013), 'Offshoring, Tasks, and the Skill-Wage Pattern', European Economic Review 61, 132 - 152.

Becker, S., Ekholm, K. \& Muendler, M. (2013), 'Offshoring and the Onshore Composition of Tasks and Skills', Journal of International Economics 90(1), 91 - 106.

Berman, E., Bound, J. \& Griliches, Z. (1994), 'Changes in the Demand for Skilled Labor within US Manufacturing: Evidence from the Annual Survey of Manufacturers', Quarterly Journal of Economics 109(2), 367-397.

Bertrand, M., Duflo, E. \& Mullainathan, S. (2004), 'How Much Should We Trust Differences-inDifferences Estimates?', Quarterly Journal of Economics 119(1), 249-275.

Blinder, A. (2006), 'Offshoring: The Next Industrial Revolution?', Foreign Affairs 85(2), 113-128.

Cameron, A., Gelbach, J. \& Miller, D. (2008), 'Bootstrap-Based Improvements for Inference with Clustered Errors', Review of Economics and Statistics 90(3), 414-427.

Costinot, A., Oldenski, L. \& Rauch, J. (2011), 'Adaptation and the Boundary of Multinational Firms', Review of Economics and Statistics 93(1), 298-308.

Crinò, R. (2010), 'Service Offshoring and White-Collar Employment', Review of Economic Studies $\mathbf{7 7}(2), 595-632$.

Ebenstein, A., Harrison, A., McMillan, M. \& Phillips, S. (2013), 'Estimating the Impact of Trade and Offshoring on American Workers Using the Current Population Surveys', Review of Economics and Statistics. forthcoming.

Feenstra, R. \& Hanson, G. (1996), Political Economy of Trade Policies: Essays in Honor of Jagdish Bhagwati, MIT Press, Cambridge, chapter Foreign Investment, Outsourcing and Relative Wages, pp. 87-127.

Feenstra, R. \& Hanson, G. (1999), 'The Impact of Outsourcing and High-Technology Capital on Wages: Estimates for the United States, 1979-1990', Quarterly Journal of Economics 114(3), 907-940.

Firpo, S., Fortin, N. \& Lemieux, T. (2011), 'Occupational Tasks and Changes in the Wage Structure', IZA Discussion Paper (5542).

Gartner, H. (2005), 'The Imputation of Wages Above the Contribution Limit with the German IAB Employment Sample', FDZ Methodenreport 2, 2005.

Geishecker, I. (2006), 'Does Outsourcing to Central and Eastern Europe Really Threaten Manual Workers' Jobs in Germany?', World Economy 29(5), 559-583. 
Geishecker, I. \& Görg, H. (2013), 'Services Offshoring and Wages: Evidence from Micro Data', Oxford Economic Papers 65(1), 124 - 146.

Goos, M., Manning, A. \& Salomons, A. (2009), 'Job Polarization in Europe', American Economic Review P\&P 99(2), 58-63.

Goos, M., Manning, A. \& Salomons, A. (2010), 'Explaining job polarization in europe: The roles of technology, globalization and institutions', Centre for Economic Performance Discussion Paper (1026).

Griliches, Z. \& Hausman, J. (1986), 'Errors in Variables in Panel Data', Journal of Econometrics 31(1), 93-118.

Grossman, G. \& Rossi-Hansberg, E. (2008), 'Trading Tasks: A Simple Theory of Offshoring', American Economic Review 98(5), 1978-1997.

Hijzen, A., Görg, H. \& Hine, R. (2005), 'International Outsourcing and the Skill Structure of Labour Demand in the United Kingdom', Economic Journal 115(506), 860-878.

Kemeny, T. \& Rigby, D. (2012), 'Trading Away What Kind of Jobs? Globalization, Trade and Tasks in the US Economy', Review of World Economics 148(1), 1-16.

Kohler, W. (2004), 'International Outsourcing and Factor Prices with Multistage Production', Economic Journal 114(494), C166-C185.

Levy, F. \& Murnane, R. (2004), The New Division of Labor: How Computers are Creating the Next Job Market, Princeton University Press.

Liu, R. \& Trefler, D. (2011), 'A Sorted Tale of Globalization: White Collar Jobs and the Rise of Service Offshoring', NBER Working Paper (17559).

Ohnsorge, F. \& Trefler, D. (2007), 'Sorting It Out: International Trade with Heterogeneous Workers', Journal of Political Economy 115(5), 868-892.

Roy, A. (1951), 'Some Thoughts on the Distribution of Earnings', Oxford Economic Papers 3(2), 135-146.

Schmucker, A. \& Seth, S. (2009), 'BA-Employment Panel 1998-2007, Codebook (only in German)', FDZ Datenreport 1.

Spitz-Oener, A. (2006), 'Technical Change, Job Tasks, and Rising Educational Demands: Looking Outside the Wage Structure', Journal of Labor Economics 24(2), 235-270.

Wright, G. (2012), 'Revisiting the Employment Impact of Offshoring', mimeo University of Essex 


\section{Data Appendix}

\section{Labor market data from the BA Employment Panel}

The BA Employment Panel ("BA-Beschäftigtenpanel") is a $2 \%$ random sample derived from official German employment records based on social security data. It holds information on a wide variety of individual worker characteristics. It is quarterly in nature, yet, its income information does not provide this detail since many employers only submit one record a year. For both the cost share calculations and the employment share calculations, yearly information from the December waves only were used. Before calculating cost and employment shares, the sample is restricted to full-time regular employees. In the calculation of wage cost shares, occupation-industry cells with less than 4 observations are dropped. Assumed imputed incomes, so-called "Fortschreibefälle", are deleted. Income below 400 Euro and above 10,000 Euro per month is regarded as measurement error and is deleted. One potential issue with administrative data is that income is top-coded at the legal threshold of social security contributions. This issue is likely of less relevance in the manufacturing industry, however. Note that those results in this paper which are based on employment share calculations as measures of labor demand are completely unaffected by this limitation. Additionally, from a theory perspective, the main effect is operative at the bottom of the wage distribution - where offshoring induced re-sorting occurs - and thus does not rely on variation at the top of the distribution. Nevertheless, all main results from table 2 were tested with cost shares based on imputed incomes following Gartner (2005). There was hardly any effect on the coefficients, which were all similar in magnitude and all significant at conventional levels.

\section{Data and method used for calculation of task intensities}

The data holding information on task performance stem from the BIBB/IAB study: "Acquisition and Application of Occupational Qualifications 1998/99". This survey contains about 34,000 individual observations. Among other things, individuals are asked if and how often they perform certain tasks. Table 6 lists these tasks. In order for a task performance to be counted, the individual has to indicate "often" from a scale with further options "sometimes" and "never". The number of tasks of a certain category are then divided by the total number of tasks an individual reports to perform often. The individual values are aggregated to the occupational level. It is assumed that the average task content of any given occupation does neither differ across industries nor across individual characteristics (age, gender, ...) nor working arrangements (full-time versus part-time). 
Table 6: Classification of tasks

\begin{tabular}{|c|c|c|}
\hline Classification used here & $\begin{array}{l}\text { Spitz-Oener } \\
\text { classification }\end{array}$ & Tasks \\
\hline \multirow{3}{*}{$=N$} & $\begin{array}{l}\text { non-routine } \\
\text { analytic }\end{array}$ & $\begin{array}{l}\text { Researching, analyzing, evaluating and planning, making } \\
\text { plans/contructions, designing, sketching, working out rules/ pre- } \\
\text { scriptions, and using and interpreting rules }\end{array}$ \\
\hline & $\begin{array}{l}\text { non-rountine } \\
\text { interactive }\end{array}$ & $\begin{array}{l}\text { Negotiating, lobbying, coordinating, organizing, teaching or train- } \\
\text { ing, selling, buying, advising customers, advertising, entertaining } \\
\text { or presenting, and employing or managing personnel }\end{array}$ \\
\hline & $\begin{array}{l}\text { non-routine } \\
\text { manual }\end{array}$ & $\begin{array}{l}\text { Repairing or renovating houses/ apartments/ machines/ vehicles, } \\
\text { restoring art/ monuments, and serving or accommodating }\end{array}$ \\
\hline$=R$ & $\begin{array}{l}\text { routine } \\
\text { cognitive } \\
\text { routine } \\
\text { manual }\end{array}$ & $\begin{array}{l}\text { Calculating, bookkeeping, correcting texts/ data, and measuring } \\
\text { length/ weight/ temperature } \\
\text { operating or controlling machines and equipping machines }\end{array}$ \\
\hline
\end{tabular}

\section{Further data sources}

The data for the construction of the offshoring values stem from three sources. The share of imported intermediates used in the same industry as the origin industry, $\Omega$, is calculated from the import tables of the yearly input-output tables published by the German Statistical Office. Industry output and import values are from the OECD STAN database. Trade data by world region are calculated using shares derived from the OECD STAN bilateral trade database. The imports from non-OECD countries are available for 17 out of the 19 2-digit NACE 1.1 industries used here. Therefore non-OECD shares for industries 17 and 18 are identical, as well as are 21 and 22 , since these are supplied as two-industry aggregates only. Industry 15 is the composite of the (tiny) tobacco sector 16 . The main results are robust to the exclusion of these industries. Industry level $R \& D$ intensity is based on the share of $R \& D$ expenditure in industry value-added and is taken from the STAN indicators. The capital stock data used for the construction of the capital output ratios are the gross capital stocks as supplied by the OECD. Industry specific price indices for production values used as controls and in the construction of the capital output ratio are from the German Statistical Office. 